\title{
Dynamics and determinants of emigration: the case of Croatia and the experience of new EU member states
}

\author{
IVANA DRAŽENOVIĆ, mag. oec.* \\ MARINA KUNOVAC, dott. mag. des* \\ DOMINIK PRIPUŽIĆ, dipl. oec.*
}

\author{
Article** \\ JEL: J61, E65, C33 \\ https://doi.org/10.3326.pse.42.4.3
}

\footnotetext{
* We would like to thank two anonymous referees and the editor for the constructive and very useful remarks. We are particularly grateful to Evan Kraft, Gordi Sušić, Vedran Šošić, Teo Matković, Maja Bukovšak, Nina Ranilović, Davor Kunovac, Marko Mrkalj, Ervin Duraković, Karlo Kotarac and Alan Bobetko for their valuable comments during the early stages of the research. Our work also benefited a lot from the presentation and discussion during the $24^{\text {th }}$ Dubrovnik Economic Conference in June 2018. The views expressed are those of the authors and do not necessarily represent those of the Croatian National Bank. No financial support received.

${ }^{* *}$ Received: June 1, 2018

Accepted: November 4, 2018
}

The article was submitted for the 2018 annual award of the Prof. Dr. Marijan Hanžeković Prize.

Ivana DRAŽENOVIĆ

Center for Economic Research and Graduate Education - Economics Institute, Politických vězňů 7, 11121

Prague 1, Czech Republic

e-mail: Ivana.Drazenovic@cerge-ei.cz

ORCiD: 0000-0002-6738-1288

Marina KUNOVAC

Croatian National Bank, Trg hrvatskih velikana 3, 10000 Zagreb, Croatia

e-mail: marina.kunovac@hnb.hr

ORCiD: 0000-0002-3200-5928

Dominik PRIPUŽIĆ

Croatian National Bank, Trg hrvatskih velikana 3, 10000 Zagreb, Croatia

e-mail: dominik.pripuzic@hnb.hr

ORCiD: 0000-0003-3377-9260 


\section{Abstract}

This paper analyzes the emigration flows from Croatia and other new EU member states to the core EU countries after their EU accession. In order to assess the magnitude and dynamics of the recent emigration wave properly, we construct the series of indirect emigration flows, resorting to the national statistical offices of the selected core EU destination countries. We compare the Croatian experience with that of other NMS and show that the intensity of Croatia's emigration flows after EU accession is proportional to that of the Romanian and Bulgarian cases. Finally, we empirically analyze the economic and non-economic drivers of emigration from NMS to the core EU in the 2000-2016 period. Results show that both economic (measured by different GDP and labour market indicators) and noneconomic factors (capturing the EU accession, the level of corruption in the economy and demographic characteristics of the origin country population) are relevant for emigration decisions.

Keywords: emigration, EU accession, new member states, gravity model

\section{INTRODUCTION}

In mid-2013 Croatia joined the European Union (EU) and as a member state (MS) gained access to the EU single market. By becoming a part of the single market, the country benefits from "the four freedoms" - the free movement of goods, services, capital and labour, which enable more efficient reallocation of domestic factors of production, resulting in new business and trade opportunities and ultimately increasing MS growth prospects. At the same time, EU accession triggered implementation of temporary, transitional provisions restricting free labour mobility from Croatia to the labour markets of other MS. ${ }^{1}$ Despite that, one of the direct effects of EU accession and the related reallocation of domestic factors of production was also a significant emigration outflow from Croatia to other states in the EU.

Such developments raised emigration-related issues to the forefront of public debate in Croatia. Drawing on a mixture of anecdotal evidence, ad hoc surveys and social network posts, the media predominantly engaged in painting and propagating a bleak picture of the "Croatian exodus". At the same time, no proper estimate of the magnitude and nature of this emigration wave has been made, due to inaccurate migration statistics. Official migration statistics collected by the Central Bureau of Statistics in Croatia are published with a disclaimer that the numbers of emigrants are based on the self-reporting of emigration by emigrants themselves, a process clearly discouraged by a relatively burdensome procedure that results in a loss of domestic social security benefits.

\footnotetext{
${ }^{1}$ Transitional provisions do not apply on cross boarder movements of citizens for reasons other than work, but only restrict free movement of citizens for work purposes. According to the Accession Treaty for Croatia transitional provisions can apply for a maximum period of seven years $(2+3+2$ formula). More details are given in table A1, appendix 1.
} 
Therefore, in this paper we try to assess the characteristics of the recent Croatian emigration wave to EU countries. We present a comprehensive analysis of the dynamics and the main determinants of emigration from Croatia to core EU countries following EU accession, comparing the Croatian case with the experience of other new member states. ${ }^{2}$

To our knowledge, there are few analyses of the impact of the free mobility of labour on Croatian emigration flows. Potential migration flows from Croatia after EU accession are ex-ante estimated in Strielkowski, Šárková and Żornaczuk (2013), Fertig and Kahanec (2013), and Vidovic and Mara (2015). Strielkowski, Śárková and Żornaczuk (2013) find that around 220 thousand residents from Croatia were expected to live in the EU15 by 2016. The Fertig and Kahanec (2013) estimates vary between negative net migration balance and 360 thousand residents from Croatia in the EU14 by 2020, while the Vidovic and Mara (2015) estimates are between 160 and 220 thousand residents from Croatia in the EU by 2019.

Effective emigration outflows from Croatia following the EU accession are analyzed in Vidovic and Mara (2015), and Župarić-Ilijić (2016). Vidovic and Mara (2015) integrate several data sources (CBS data, Eurostat employment data, data about the stock of Croatian citizens in EU member states and various surveys). They show that emigration patterns from Croatia in 2014 intensified significantly, due to higher economic development and better quality of life in other MS, as perceived by Croatian emigrants. However, their paper analyses emigration outflows only up to 2014, due to data availability. Another overall analysis of emigration trends from Croatia is given in Župarić-Ilijć (2016). This author emphasized that Croatian net migration balance significantly worsened with the onset of the global financial crisis and in particular after the accession to the EU, and argued that official Central Bureau of Statistics migration data are underestimated and should be compared with destination country data, but provided no such estimate. Thus, in this paper, we extend existing literature in time, referring to the broader period, integrating several data sources and analyzing the movements that were effectively observed after Croatia had joined the EU in 2013. The main contributions of our paper are threefold. ${ }^{3}$

First, we construct indirect emigration flows from Croatia, following the EU accession. Currently, the Central Bureau of Statistics (CBS) in Croatia collects the

\footnotetext{
${ }^{2}$ Due to data availability, core EU countries are represented by 11 countries: Austria, Belgium, Denmark, Finland, Germany, Ireland, Italy, Luxembourg, Netherlands, Sweden and United Kingdom. New EU member states are represented by 10 countries: Bulgaria, Croatia, Czech Republic, Estonia, Hungary, Latvia, Lithuania, Poland, Slovakia and Slovenia.

${ }^{3}$ In addition, several authors implement partial analyses of emigration flows from Croatia following the EU accession. Šonje (2018) estimates family emigration by using primary school enrolment data and shows that in 2009-2016 period around 50 thousand young citizens with children left Croatia. The Croatian Employment Service uses the annual employers' survey to examine the extent of migration among the employed, and shows that in 2016 around 20 thousand employed persons emigrated from Croatia. Finally, Jurić (2017) did a detailed on line survey among Croatian emigrants in Germany and showed that although economic factors are relevant for emigration decision, there is a prevalence of non-economic factors among the motives of emigration for Croatian emigrants.
} 
data about migration flows from the Ministry of the Interior, which records only persons that have registered the change in their country of usual residence with the Ministry. Following related literature contributions (Izquierdo, Jimeno and Lacuesta, 2014; Bertoli, Brücker and Moraga, 2013) we assume that there are no clear incentives and benefits of registering in home country offices when emigrating, while on the other hand immigrants have an incentive to register when they arrive in the destination country, given that access to some basic social services in a destination country (i.e. education and health) generally requires registration. Therefore, we assume that official emigration numbers from CBS could be underestimated and resort to the European Union destination countries national statistical offices to collect numbers of registered immigrants coming from Croatia. The differences are striking. Our indirect emigration estimates show that emigration from Croatia to the core EU countries following the accession is on average around 2.6 times higher than the officially registered numbers in Croatia, with around 230 thousands people having left Croatia and settled in one of the analyzed core EU countries in the 2013-2016 period.

Secondly, we show that although emigration flows in Croatia following the accession are sizeable, they are not an isolated case. Bulgaria and Romania also experienced proportionally similar population outflows after they became member states in 2007. CEE countries that joined the EU in 2004 also saw an increase in emigration rates towards the core EU countries, though to a lower extent. Time series of indirect emigration flows from NMS show that higher emigration rates recorded after the EU accession persisted over the years. In other words, average emigration rate from NMS to the core EU countries in 2016 is on average equal to or higher than the emigration rates in the four years following accession to the EU, which corroborates the strong persistency of higher emigration rates. ${ }^{4}$ Such trends raise several serious sustainability concerns for Croatia, which will become relevant in the medium term, since the current population outflow to the core EU countries, according to the indirect emigration flows constructed, is around $2 \%$ of population each year.

The third contribution of our paper consists of empirical analyses of the main economic and non-economic determinants of emigration flows from Croatia and other NMS to the core EU countries. We believe that their evaluation provides insights that are highly important for policymakers in order to shape and implement adequate and targeted policies to mitigate emigration flows. In our analysis of relevant emigration determinants we employed a gravity model. Results obtained under alternative specifications and estimation strategies of the gravity model show that the access to the single EU market (after transitional provisions were lifted) has been a main driver of emigration flows in Croatia since 2013. However, current economic conditions and labour market indicators, together with demographic factors and prevalence of the corruption in the country also

\footnotetext{
${ }^{4}$ That is 12 or 8 years following EU accession.
} 
turned out to be significant in the determination of emigration flows among NMS and core EU countries, implying that there is a room for policymakers to alleviate the intensity of emigration pressures in Croatia.

The remainder of the paper is structured as follows: in section 2 we describe in detail the major characteristics of recent Croatian emigration flows, firstly by discussing Croatia's official emigration figures and secondly by comparing official data with data on indirect emigration from Croatia collected from national statistical offices of the core EU destination countries. In section 3 we present a comparative overview of the emigration experiences of other new EU member states following their EU accession. In section 4 we provide a basic overview of gravity models and their applicability in studying migration issues and describe the variables used in the model. In section 5 we present different specifications of the gravity models and discuss the results of the econometric analysis together with robustness checks. In section 6 we emphasize the main conclusions.

\section{DEMOGRAPHIC AND GEOGRAPHICAL CHARACTERISTICS}

\section{OF CROATIAN EMIGRANTS}

\subsection{EMIGRATION FLOWS FROM CROATIA ACCORDING TO THE CENTRAL BUREAU OF STATISTICS DATA}

As a starting point, we take a deeper look at the official Croatian migration statistics, in order to improve our understanding of the migration dynamics in Croatia. Notwithstanding existent methodological issues, and, while accepting the claim that official Croatian migrations are under-reported, we nevertheless believe that they could be under-reported systematically, which means that they still might contain some useful information about the underlying migration trends.

Looking at the big picture, we can see that prior to the global financial crisis Croatia had a positive net migration balance. However, migration flows reversed at the onset of the global financial crisis (net migration balance turned negative). Until the EU accession, negative net migration remained relatively low and stable. After Croatia became a full member of the EU in July 2013 migration flows clearly intensified (figure 1).

Figure 1 also shows that EU accession had no significant effect on the number of immigrants, while emigration outflows intensified significantly with the accession. Thus, in the remaining part of the paper we concentrate exclusively on gross emigration outflows and analyze emigrants' main characteristics.

Available data provide a basis for a simple demographic analysis of Croatian emigrants. Numbers suggest that there is an almost equal share of male and female emigrants throughout the period, with the share of male emigrants slightly increasing at times of high migration (figure 2). 


\section{Figure 1}

Net migration balance of Croatia between 2001 and 2016, Central Bureau of Statistics data, net migration

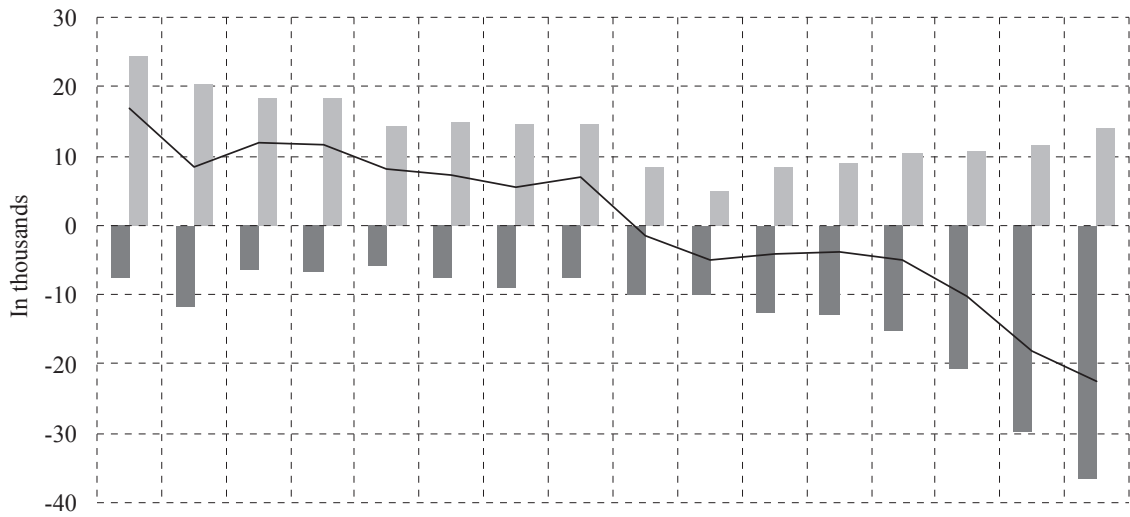

2001200220032004200520062007200820092010201120122013201420152016

Emigration Immigration - Net migration

Note: Net migration $=$ number of immigrants - number of emigrants, in thousands

Source: $C B S$.

Figure 2

Structure of emigrants from Croatia by sex between 2002 and 2016, Central Bureau of Statistics data, gross emigration flows

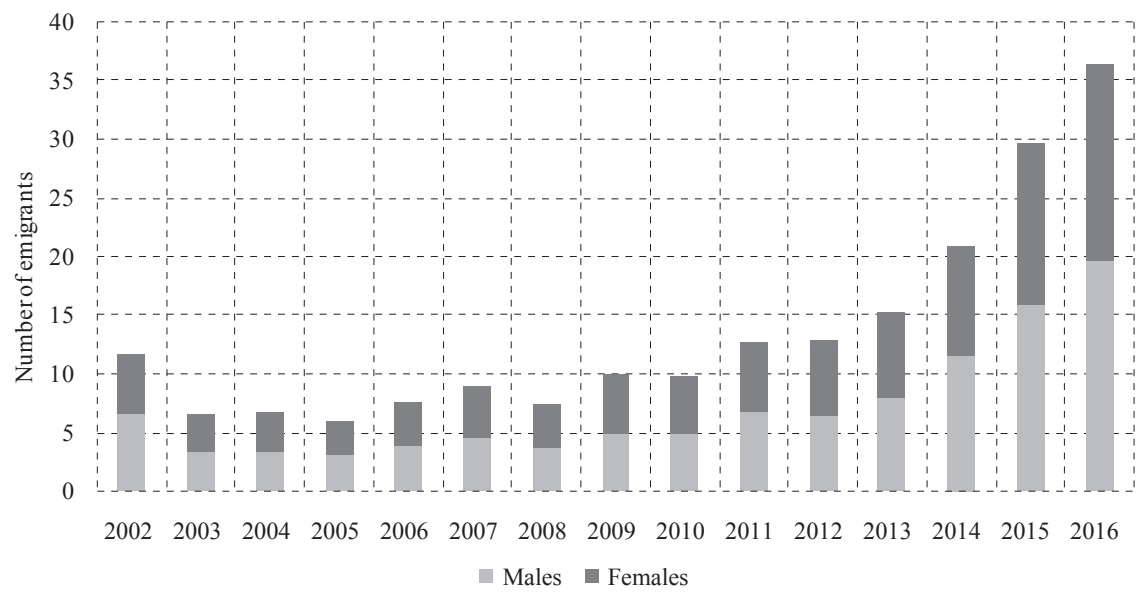

Note: In thousands.

Source: $C B S$.

The age structure of emigrants suggests that there was a structural shift towards younger emigrants in the last emigration wave. Firstly, there is a striking increase in the number of youngest emigrants (age 0-15), and secondly it appears that the decrease in the average age of the emigrants is accelerating. Our estimates show that the average age of emigrants in the period between 2001 and 2013 was 41.5 
years, but dropped sharply over next three years and reached 33.6 years in 2016 (figure 3). These results are in line with Šonje (2018). The author estimates that in 2009-2016 period around 50 thousand young citizens with children left Croatia permanently. ${ }^{5}$

\section{Figure 3}

(a) Relative share of different age groups of emigrants and average age of emigrant between 2002 and 2016, (b) Number of emigrants by different age groups between 2002 and 2016, Central Bureau of Statistics data, gross emigration flows
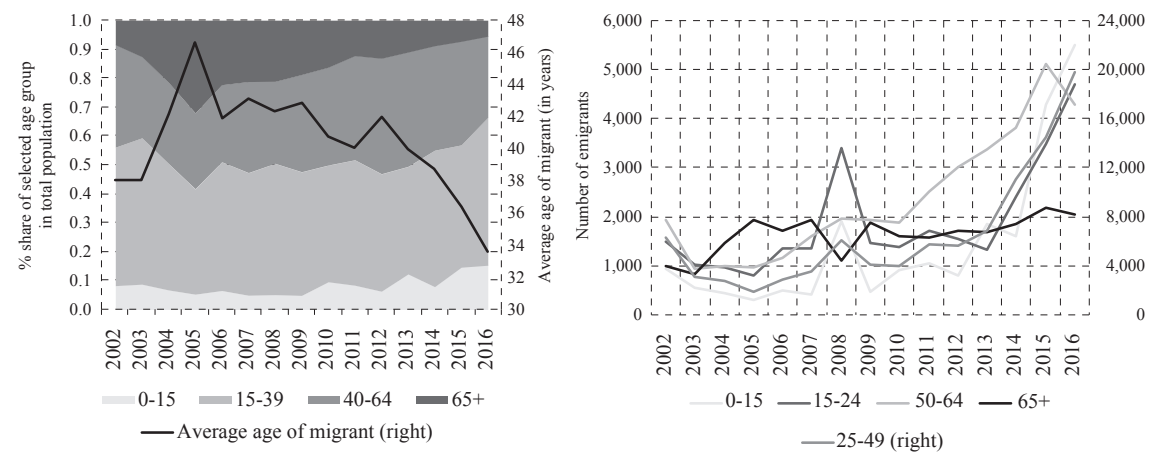

Source: CBS.

Turning to the distribution of emigrants across Croatian regions, again there is a very clear compositional change, towards the end of the analyzed period, with a growing proportion of emigrants from less-developed regions. Following the relatively stable situation during the 2000 s, the deep and prolonged domestic recession pushed up emigration more or less gradually in almost all regions. After the EU accession, there was a rapid and pronounced growth of emigration from all regions, albeit at a different pace. Emigration flows were much stronger in the regions with the highest unemployment. As a result, looking at the share of migrants in their population in 2016, Croatian regions can be broadly divided into two groups: one with the ratio of migrants to domestic population close to or above 1\% (Eastern Croatia, Central Croatia, Lika and Gorski Kotar), and other, economically more advanced regions with the ratio of around $0.66 \%$ (figure 4 ). Therefore, even though emigration is a country-wide problem, the intensity of emigration flows (as a percentage of total population) is a much stronger phenomenon in the economically less developed regions (figure 5).

\footnotetext{
${ }^{5}$ Estimates are based exclusively on households with children (obtained by comparison of expected and effective primary school enrolment) and are considered to represent irreversible emigration, based on the assumption that child integration in system of destination countries strongly disincentives return-migration.
} 
Structure of emigrants from Croatia by region between 2001 and 2016, Central Bureau of Statistics data, gross emigration flows

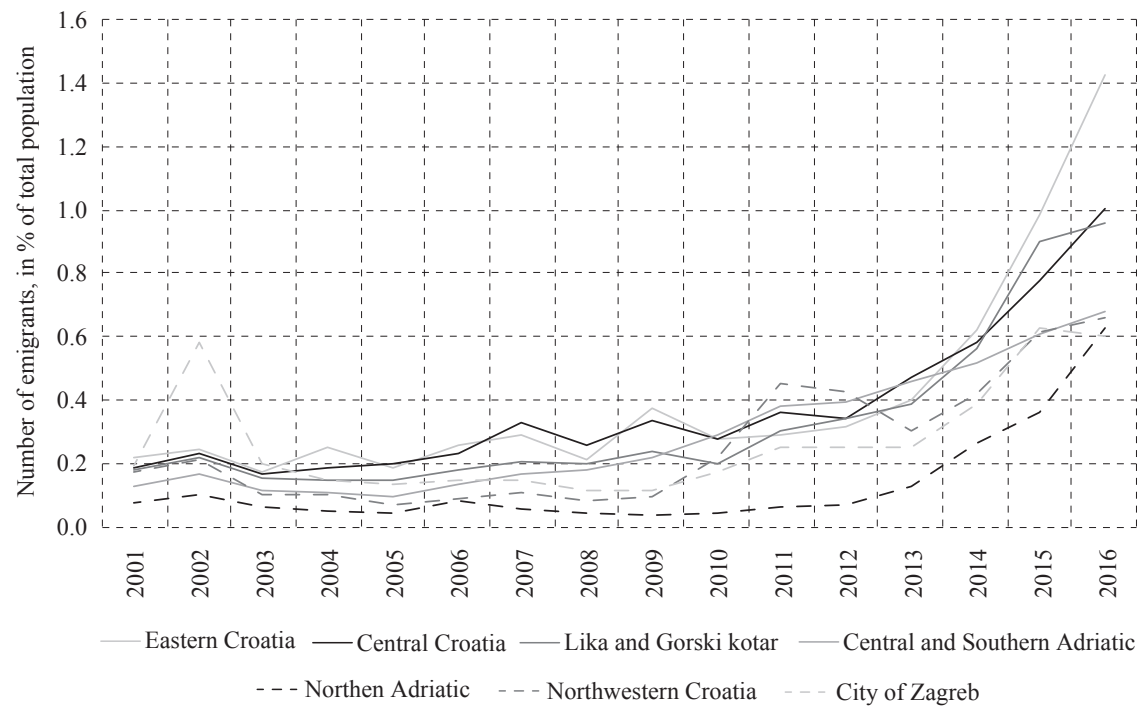

Notes: Eastern Croatia encompasses Virovitičko-podravska, Požeško-slavonska, Brodskoposavska, Osječko-baranjska and Vukovarsko-srijemska counties. Central Croatia encompasses Zagrebačka, Sisačko-moslavačka, Karlovačka and Bjelovarsko-bilogorska counties. Lika and Gorski kotar encompass Primorsko-goranska and Ličko-senjska counties. Central and Southern Adriatic encompass Zadarska, Šibensko-kninska, Splitsko-dalmatinska and Dubrovačkoneretvanska counties. Northen Adriatic refers to Istarska County. Northwestern Croatia encompass Krapinsko-zagorska, Varaždinska, Međimurska and Koprivničko-križevačka counties.

Source: CBS.

\section{Figure 5}

Unemployment rate and share of emigrants by county in 2016, Central Bureau of Statistics data, gross emigration flows

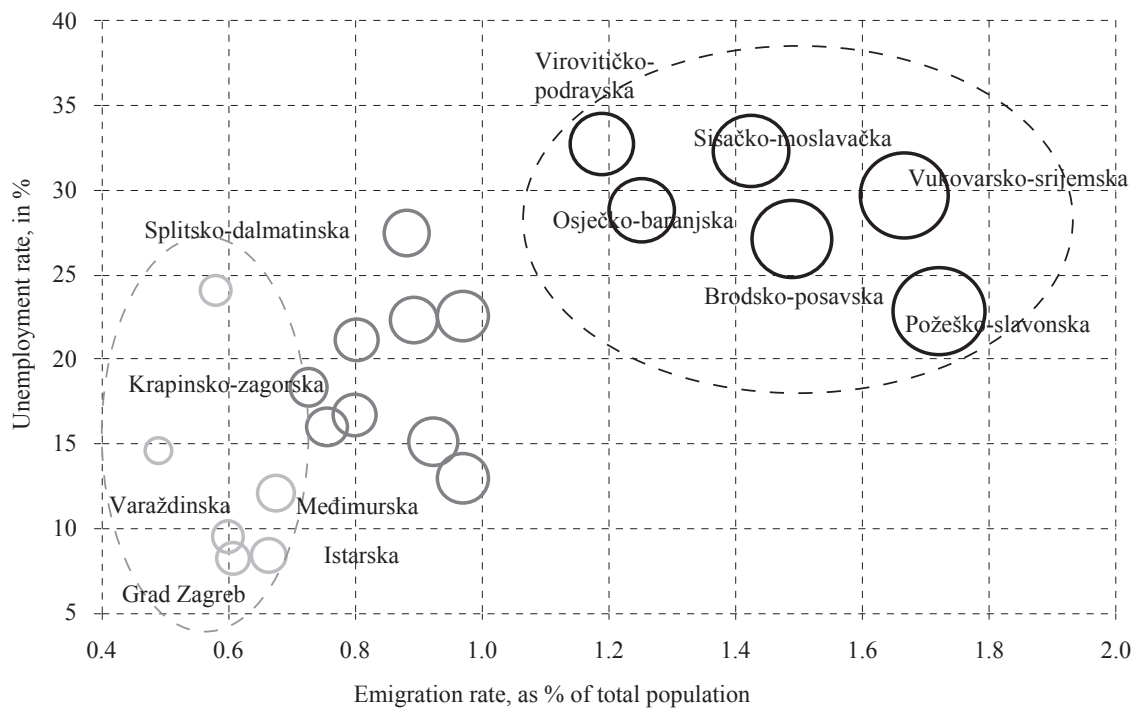

Note: The size of the circles correspond to the emigration rate, as \% of total population of the county.

Source: $C B S$. 
Finally, CBS data show that slightly more than $85 \%$ of emigrants from Croatia after the EU accession was directed to three EU countries; Germany, Austria and Ireland. Figure 6 compares main emigration destinations of Croatians in the EU before and after Croatian accession. Although total emigration flows towards the EU increased significantly, the composition of the main destinations remained almost unchanged from the period before accession. The only exception is Ireland, since emigration to Ireland before the EU accession was almost non-existent in Croatia, while in 2016 Ireland become third biggest destination for Croatian emigrants. In addition, EU accession caused a change in relative position between Germany and Austria, two main emigration destinations, with even more emigrants going to Germany. This is a direct consequence of Austria's decision to extend the application of transitional provisions for Croatian citizens until June 2018. After 2018 we expect the share of Croatians heading towards Austria to increase, unless Austria prolongs the application of the transitional provisions until $2020 .^{6}$

\section{Figure 6}

(a) Main EU emigration destinations for Croatians in 2010, (b) Main EU emigration destinations for Croatians in 2016, Central Bureau of Statistics data, gross emigration flows

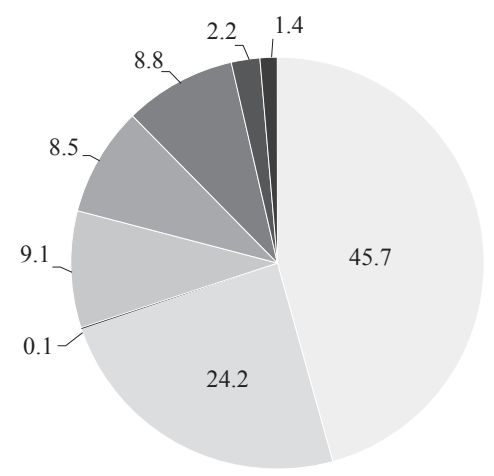

Total emigration to EU in 2010 - 1,697 persons

$\begin{array}{ll}\text { Germany } & \text { Italy } \\ \text { Austria } & \text { Slovenia } \\ \square \text { Ireland } & \text { Sweden } \\ \text { Other EU countries } & \square \text { United Kingdom }\end{array}$

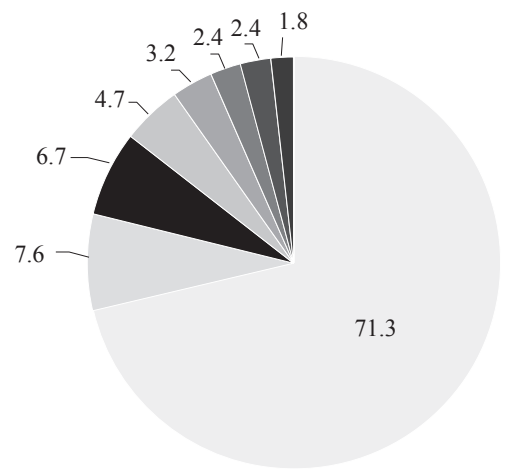

Total emigration to EU in 2016 - 28,659 persons

$\begin{array}{ll}\text { Germany* } & \text { Italy* } \\ \text { Austria** } & \text { Slovenia } \\ \square \text { Ireland } & \text { Sweden } \\ \text { Other EU countries } & \square \text { United Kingdom** }\end{array}$

Note: * Germany and Italy lifted transitional provisions for Croatia in 2015. ** UK and Austria are applying transitional provisions until June 2018, with possible extension until 2020.

Source: $C B S$.

\footnotetext{
${ }^{6}$ Prolongation of application of transitional provisions in the period from June 2018 until June 2020 is possible only in the case of serious disturbances for the Austrian labour market that would otherwise occur.
} 


\subsection{EMIGRATION FROM CROATIA ACCORDING TO NATIONAL STATISTICAL OFFICES OF CORE EU COUNTRIES}

The Croatian Central Bureau of Statistics detailed data about emigration presented so far are useful for an analysis of some main characteristics of Croatian emigrants. However, as previously explained in the Introduction, the official number of emigrants published by the Central Bureau of Statistics in Croatia is based on the people who voluntarily registered their departure with the authorities, while standard migration theory predicts that migrants are much more likely to register in the country of destination than in the country of origin. ${ }^{7}$ Therefore, in addition, we construct an indirect emigration flow taking as a starting point the immigration statistics from the national statistical offices of the following core EU countries: Germany, Denmark, Austria, Ireland, Belgium, Netherlands, Italy, Finland, Sweden, Luxembourg and United Kingdom. For UK and Ireland, immigration statistics are not available, so we use the individually appointed national insurance numbers (NINo) in the UK and personal public service numbers (PPS) in Ireland that are commonly used in the literature (Hazans and Philips, 2011). We analyze the period from 2000 until 2016 and for each year in the sample, we consult official immigration statistics of the selected core EU countries and take the number of immigrants coming from Croatia.

Where available, our preferred choice is statistics that register immigrants from Croatia according to the country of birth principle (as in Netherlands, Italy, UK and Belgium) or country of previous residence principle (as in Germany and Denmark). ${ }^{8}$ Immigration flows registered according to citizenship principle (as in Sweden, Finland, Luxembourg and Austria) could be inaccurate since they also include migrants from Bosnia and Herzegovina (and other countries) having Croatian (or dual) citizenship. ${ }^{9}$ According to Jurić (2017) in a survey of Croatian emigrants to Germany, around $20 \%$ of emigrants registered as Croatian citizens in Germany actually emigrated from Bosnia and Herzegovina. This is the reason why we have avoided using migration numbers based on the citizenship principle, if the country of birth principle or country of previous residence principle was also available among migration statistics. Nevertheless, given that for some countries migration statistics are available only based on the citizenship principle, indirect emigration flows constructed with resort to the national statistical offices of core EU countries and presented in the remaining part of the paper should be interpreted as an upper bound for emigration outflows from Croatia. Detailed information about the construction of indirect emigration flows is given in appendix 1 . Comparison between constructed indirect emigration flows from Croatia based on

\footnotetext{
${ }^{7}$ Illustrative case in point is a Polish example. Following the EU accession Poland experienced a strong emigration flows. At some point policymakers realized that the official statistics grossly underestimate the extent of emigration. As a result, research project has been initiated in Poland in order to properly estimate the true numbers. The upgraded and consolidated sources raised the official emigration numbers by a factor ten (Statistics Poland, 2011).

${ }^{8}$ Destination country can register immigrants according to the following principles: country of birth principle, country of previous residence principle and citizenship principle. Registration of immigrants according to the different principles is defined by Eurostat International Migration Statistics.

${ }^{9}$ For Ireland personal public service number the principle for registration of immigrants is not denoted.
} 
data published by national statistical offices of the core EU countries and official Central Bureau of Statistics data are represented in figure 7. ${ }^{10,11}$

\section{Figure 7}

Indirect emigration flows from Croatia to the core EU countries according to national statistical offices of core EU countries, compared to the official emigration numbers to EU 27 countries according to Central Bureau of Statistics, gross emigration flow

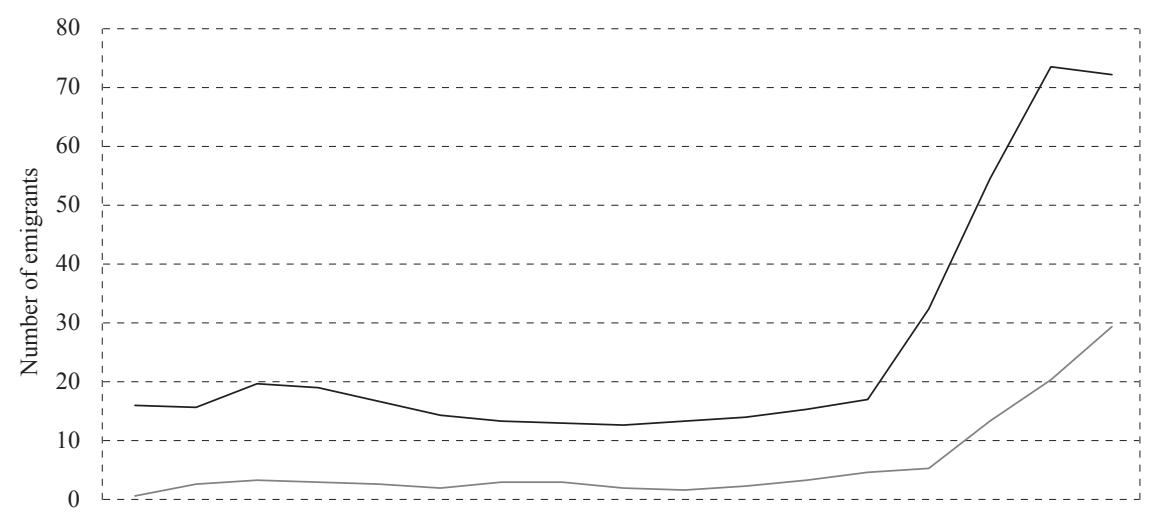

20002001200220032004200520062007200820092010201120122013201420152016

— Indirect emigration numbers - from national statistical offices of core EU countres

Official Croatian Bureau of Statistics emigration to EU 27

Note: Official Central Bureau of Statistics emigration number for emigration in EU 27. Core EU countries are represented by 11 countries, due to data availability: Austria, Belgium, Denmark, Finland, Germany, Ireland, Italy, Luxembourg, Netherlands, Sweden and United Kingdom, in thousands.

Source: CBS, national statistical offices of the core EU countries.

The differences in emigration outflows between the two sources are striking. According to the indirect estimates of emigration, 230 thousand persons emigrated from Croatia to the core EU countries in the period from 2013-2016. On the other hand, official data report 61 thousand emigrants in 2013-2016 period directed towards the selected core EU countries, and 102 thousand emigrants in total during the same time period. However, the difference between the mirror statistics of Croatia and core EU destination countries is expected to decrease in the future. This would reflect the fact that by the end-2016 the Croatian Tax Administration encouraged Croatian migrants to change their residency status with authorities in order to

\footnotetext{
${ }^{10}$ According to the Central Bureau of Statistics, national statistical offices of the selected core EU countries represent broadly around $90 \%$ of total emigration to the European Union from Croatia over the entire sample period, which makes them a valid and representative indicator of total emigration flows towards the EU. ${ }^{11}$ We have also estimated total emigration flows from Croatia, by putting together (1) indirectly constructed emigration flows to the core EU countries and (2) Central Bureau of Statistics official emigration data for all other emigration destinations, i.e. "the rest of the world". The same approach is followed in order to construct an approximation of total immigration flows in Croatia. Calculation details of total net emigration are given in appendix 2. According to our discretional combination of different data sources, net emigration from Croatia is estimated to be around 155 thousands person in the 2013-2016 period.
} 
avoid double taxation of their income. ${ }^{12}$ The threat of double taxation of income probably incentivized migrants to be more prompt in registering their departure and changing their residence in their origin country offices. ${ }^{13}$

Overall, the discrepancies between the mirror statistics of origin and destination countries are common in migration statistics and most other countries are also faced with similar challenges. Thus, in our analysis we will adopt the same principle for other NMS: Bulgaria, Romania, Poland, Czech Republic, Slovakia, Slovenia, Hungary, Latvia, Lithuania and Estonia and construct indirect emigration flows for these countries referring to the immigration statistics of national statistical offices of the core EU countries.

\section{MIGRATION FLOWS IN OTHER NEW EU MEMBER STATES}

\section{AFTER THE EU ACCESSION}

In this section, by looking into the emigration experience of other new EU members, we tried to gain additional insight about some additional characteristics of emigration flows caused by EU accession, such as the average structure of emigrants (according to main demographic attributes), stability of the flows, number of years after the accession needed to reach a plateau, the likely duration of an emigration wave and possible reversal points.

Detailed migration data from national statistical offices of the new EU member states, allow us to analyze the main attributes of emigrants from NMS in order to look for some substantial differences or similarities in migration flows between countries. According to figure 8, data about the age structure of emigrants does not follow any single path across countries. However, for all countries in the sample, the average age of emigrant in 2016 is similar, ranging broadly from the low to the mid-thirties. At the same time, the median age of the total population is rapidly increasing, which in most countries widens the gap between the average population and average emigrant age. This situation makes the emigration outflows of relatively younger citizens even more concerning in terms of the long-term sustainability of social services (such as public pensions and health).

Comparison of top emigration destinations for emigrants coming from NMS reveals that Germany is ranked among the top three emigration destinations for all countries in the sample. The Croatian main emigration destinations, Austria and the United Kingdom, are also the second most frequent EU destinations for emigrants from NMS in 2016 (table 1). ${ }^{14}$

\footnotetext{
${ }^{12}$ At the beginning of 2017 Croatian government adopted the Ordinance for the implementation of the General Tax Act (OG 30/17) that clarified the process of determination of residency status for tax purposes and induced migrants to register their change of residency within authorities to avoid double income taxation.

${ }^{13} \mathrm{CBS}$ is constantly working on improving migration data sources, so part of the observed developments might reflect underlying methodological changes. For example, in 2011 the CBS changed its definition of migrants from people who registered their departure/arrival to people who are absent from their usual place of residence in a one year period.

${ }^{14}$ Nevertheless, there are some peculiarities among main emigration destinations between NMS. Finland was the main destination for emigrants from Estonia, and Spain for emigrants from Romania in 2016, reflecting their cultural and historical linkages.
} 


\section{Figure 8}

New MS emigrants' average age and median age of population, 2000-2016, national statistical offices of NMS countries, gross emigration flows

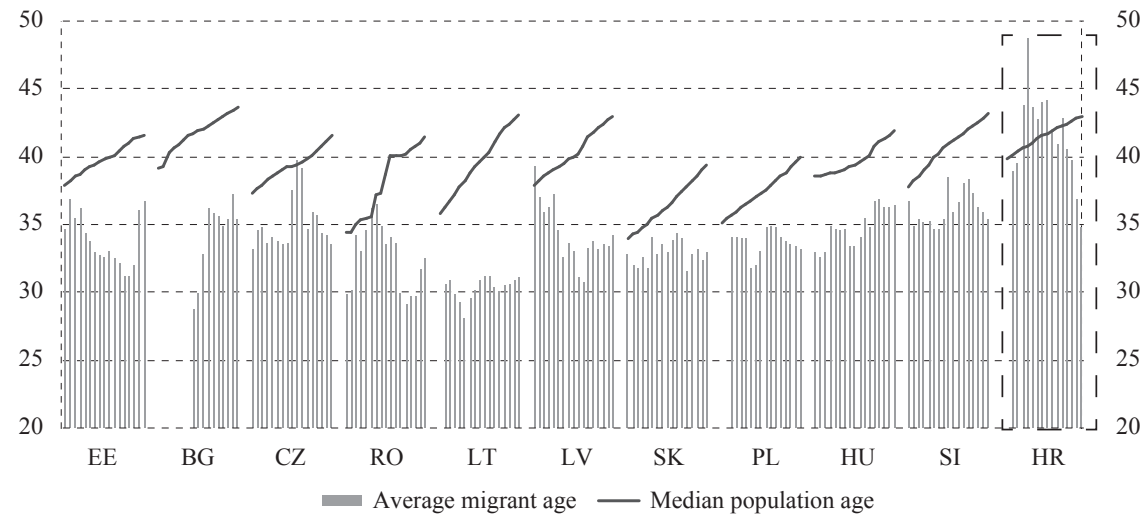

Sources: CBS, national statistical offices and Eurostat; authors'calculations.

\section{TABLE 1}

Main EU emigration destinations for NMS in 2016 (in \% of total EU emigration), national statistical offices of NMS countries, gross emigration flows

Origin country Top 3 emigration destinations in EU, as \% of total EU emigration

\begin{tabular}{|c|c|c|c|}
\hline Bulgaria & $\mathrm{n} / \mathrm{a}$ & $\mathrm{n} / \mathrm{a}$ & $\mathrm{n} / \mathrm{a}$ \\
\hline Croatia & Germany, 71 & Austria, 8 & Ireland, 7 \\
\hline Czech Republic & Slovakia, 60 & Germany, 9 & Poland, 6 \\
\hline Estonia & Finland, 63 & United Kingdom, 8 & Germany, 7 \\
\hline Hungary & Germany, 32 & Austria, 27 & United Kingdom, 17 \\
\hline Latvia & $\mathrm{n} / \mathrm{a}$ & $\mathrm{n} / \mathrm{a}$ & $\mathrm{n} / \mathrm{a}$ \\
\hline Lithuania & United Kingdom, 60 & Ireland, 11 & Germany, 10 \\
\hline Poland & Germany, 43 & United Kingdom, 28 & Netherlands, 8 \\
\hline Romania $^{a}$ & Spain, 24 & Germany, 17 & Italy, 16 \\
\hline Slovakia & Czech Republic, 38 & Austria, 27 & Germany, 10 \\
\hline Slovenia & Germany, 27 & Austria, 27 & Croatia, 12 \\
\hline
\end{tabular}

${ }^{a}$ Percentage of total emigration.

Sources: CBS, national statistical offices and Eurostat.

Given that similar core EU countries dominate as the main emigration destinations to Europe for NMS, this corroborates our decision to construct indirect emigration flows for NMS by resorting to the national statistical offices of core EU countries, as we did for Croatia. Thus, in the remaining part of this section we use data about indirect emigration flows from NMS to the core EU countries and employ them to compare the dynamics and intensity of migration outflows among the NMS.

Comparison of the indirect emigration flows from other NMS to core EU countries shows that the intensity of emigration flows from Croatia following the accession is not unique in its size, given the experience of other economically less 
developed member states (Bulgaria and Romania), but also that emigration flows from NMS following the EU accession in 2004 were significantly lower (figure 9). Another important pattern arises from the analysis of NMS emigration flows, since it is visible that a rise in the average migration rate towards the core EU countries following EU accession is not a temporary, one-off reaction to accession to the common EU market. According to figure 10, the average emigration rate in 2016 is equal to, or higher than the average emigration rate in four years following the EU accession, pointing to the persistence of intensive emigration flows. ${ }^{15}$

\section{Figure 9}

Indirect emigration flows from NMS to the core EU countries, national statistical offices of core EU countries, gross emigration flows
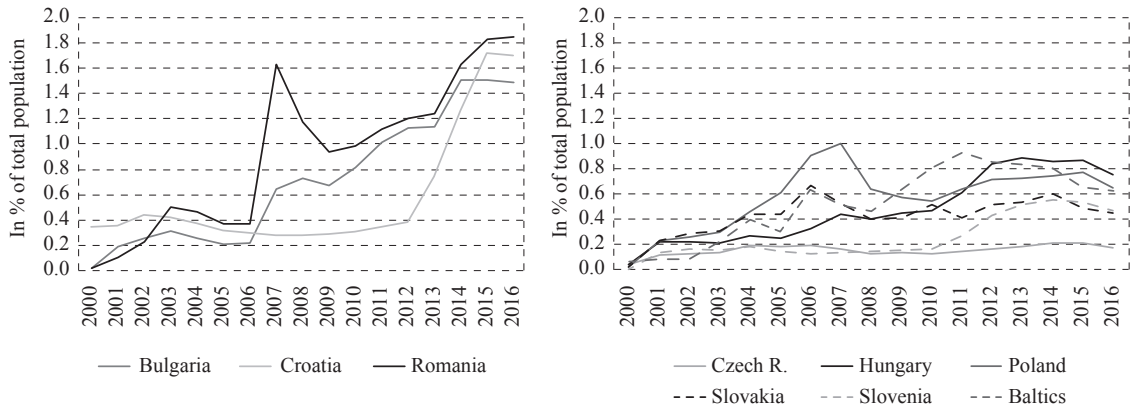

Note: Dashed lines denote the years of EU accession.

Source: National statistical offices of the core EU countries.

\section{Figure 10}

Indirect emigration flows of NMS in time, national statistical offices of core EU countries, gross emigration flows

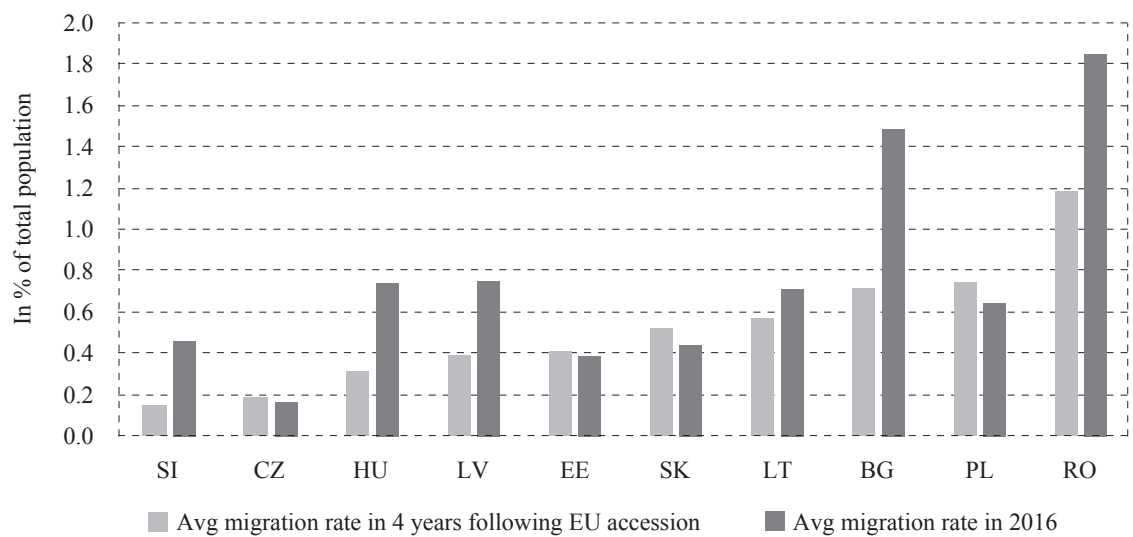

Source: National statistical offices of the core EU countries.

\footnotetext{
${ }^{15}$ However, all member states but Croatia gained access to the common EU market prior to the onset of the global crisis. Only Croatia joined the EU after six consecutive years of economic distress. This might have created an additional pressure on migration outflows from Croatia. However, proper evaluation of this phenomenon will be possible only with some time delay.
} 
A careful consideration must also be given to the influence of the economic cycle on emigration. Persistence of increased emigration flows from NMS to core EU countries in the decade following EU accession could reflect the impact of the economic crisis that started in 2009 on emigration decisions. Figure 11, in both panel (a) and (b), shows that economic conditions are indeed related to intensity of emigration.

\section{Figure 11}

Average emigration flow, as \% in total population from 2011 to 2016, compared to average unemployment rate (a) and average GDP PC in PPS, (b) national statistical offices of core EU countries, gross emigration flows
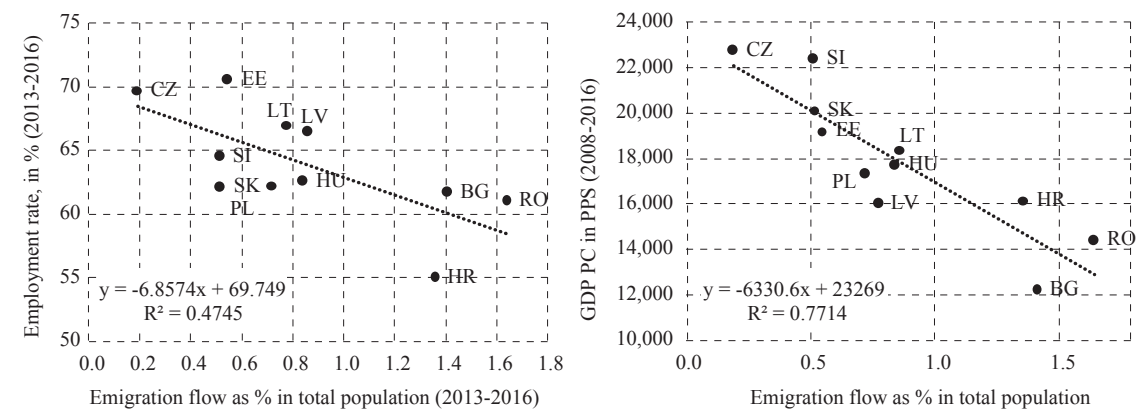

Source: Eurostat and national statistical offices of the core EU countries.

The NMS had rather different crisis and post-crisis experiences. Poland experienced no recession but faced sizable emigration flows, some countries recovered rather quickly after the initial shock (the Baltics, Slovakia), while others experienced a double-dip recession (Slovenia) or a very deep and prolonged recession (Croatia). In addition, the economic slack was global in nature, i.e. the worsening of economic conditions was not restricted only to NMS but was also present in most of the core EU countries, thus altering to some extent the relative benefits between origin and destination countries. As a result, a simple comparison of various economic performance indicators and the intensity of emigration flows can provide only a partial and limited insight into the relative importance of different economic and non-economic determinants of migration flows. In the next section we thus resort to formal econometric analysis using a gravity model to examine the main determinants of emigration in Croatia and other new EU member states to the core EU countries in the 2000-2016 period.

\section{GRAVITY MODEL OF MIGRATION}

The application of Newtonian physics in economics started with Tinbergen (1962), who used a gravity model to explain international trade flows. Flowerdew and Salt (1979) introduced the gravity model in the context of migration analysis, and it soon become widely used to analyze different migration determinants. However, some authors claim that the first application of a gravity model to explain migration patterns goes back to Ravenstein who used it to analyze migration patterns in $19^{\text {th }}$ century Britain (Anderson, 2011). 
Notwithstanding their long history, gravity models have experienced a revival since the early 2000s, due to much improved bilateral migration data (Ramos, 2016) and the emergence of statistical theories appropriate for studying spatial interaction. The reasons for the popularity of gravity models in migration analysis are trifold: intuitive consistency with migration theories; ease of estimation in its simplest form; goodness of fit in most applications (Poot et al., 2016). Gravity models assume migration flows (M) between the origin country $i$ and destination country $j$ in time $t$ are proportional to the product of their populations (P) (which are in migration contexts used as proxies for the concept of mass from standard gravity model) and inversely proportional to the distance (D) between them.

$$
M_{i j t}=\alpha_{0} P_{i t}^{\alpha_{1}} P_{j t}^{\alpha_{2}} D_{i j t}^{\alpha_{3}}
$$

Gravity models in their original form are purely non-theoretical, so they are usually enriched with different variables capturing traditional pull and push factors of migration following human capital theory approach to migration developed by Sjaastad (1962), and Harris and Todaro (1970). The authors consider migration decision as a complex form of investment in human capital that is influenced by future expected income levels and the relative probability of employment opportunities in destination and origin countries. ${ }^{16}$ More formal arguments for the use of an extended vector of explanatory variables in migration analysis can be derived from the Random utility model introduced in migration literature by Borjas (1987), and Grogger and Hanson (2011) that provided micro foundations in the context of migration analysis. Reflecting these considerations, the gravity model used in this paper is augmented by an additional set of explanatory variables covering different economic, demographic and educational factors, as well as the level of corruption in the country.

The dependent variable is the gross flow of emigrants from NMS to the core EU country in each year for 2000-2016 period. In order to trace emigration flows accurately, we rely on immigration statistics of the selected receiving countries as available from national statistical offices of the core EU countries, as explained in section 2 .

Explanatory variables used in the analysis are related to traditional pull and push factors of migration presented in literature. The basic specification of our model contains GDP per capita in purchasing power parity of origin and destination country, relative size of populations between countries based on Eurostat data and geographical distance between capitals of destination and origin countries downloaded from CEPII's geo-distance database. Moreover, our basic specification also contains the variable capturing the effect of EU accession. The variable is based on transitional provisions on the free movement of workers from new EU

\footnotetext{
${ }^{16}$ Income levels are usually approximated by GDP per capita in PPP terms given that wage data are not comparable across countries.
} 
member states following the EU enlargement in 2004, 2007 and 2013, as reported by the European Commission. Following the EU enlargement, several core EU states decided to apply transitional provisions on the free movement of workers from NMS, and effectively postpone the full liberalization of their labour markets. Thus for each pair of origin and destination countries in the sample, the dummy variable associated to transitional provisions takes the value 1 in the year that the core EU country lifted its restrictions on the free movement of workers coming from the respective NMS.

In the extended version of our model we include additional variables accounting for some additional characteristics of origin and destination countries. Following Lamberty (2015) we use data from the World Governance Index (WGI) database and include a corruption index for origin and destination country as explanatory variables in our analysis, to evaluate if differences in corruption between countries are a relevant factor in explaining observed emigration patterns. From among the different WGI indexes evaluating the quality of governance and institutions from different aspects, we have opted for the inclusion of the corruption index in our main specification following Poprawe (2015) who shows that corruption increases emigration, since it retards the economic development of the country and creates an insecure living and economic environment. ${ }^{17,18}$ We also evaluate the impact of origin country population attributes on migration outflows. Following Sprenger (2013) we include the share of persons educated to tertiary level in total population of origin country to test whether higher emigration flows are associated with higher skill levels. The impact of demographic characteristics of origin population on emigration flows is measured through the share of young people (persons aged 20-34) in total population of origin country as an approximation of the potential emigration pool.

Finally, we include alternative variables for economic performance of the country. We find this relevant since Bertoli, Brücker and Moraga (2013), and Beine et al. (2017) argue that relative difference in GDP per capita in purchasing power standard represents a difference in level of economic development between two countries, which is relevant for emigration decisions, but that current and future economic prospects, not captured by relative GDP per capita in PPS, are also important. Bertoli, Brücker and Moraga (2013), and Beine et al. (2017) argue that differences in GDP per capita in PPS are already captured by the inclusion of origin and destination fixed effects. Additionally, economic distress arising during the crisis period causes changes in future economic prospects that not reflected in a timely way in the level of GDP per capita in PPS. Therefore, in the extended specification of our model we substitute for GDP per capita in PPS with short-

\footnotetext{
${ }^{17}$ Vukovic (2017) shows that the Croatian economy is permeated by corruption since the political system is characterized by systematic corruption, on national and local levels. Also, WGI corruption index data point to a substantial gap in corruption incidence between most NMS and core EU countries in general.

${ }^{18}$ As a main alternative to the corruption index we could have used the governance index from the same database. Estimation results obtained with the governance index as independent variable are shown in appendix 3 .
} 
term indicators of economic activity - employment rate and output gap of origin and destination country. ${ }^{19}$ These variables capture how changing growth prospects and labour market opportunities affect emigration across countries.

Detailed descriptions of all variables and respective data sources are provided in appendix 1 .

In order to evaluate the main determinants of migration flows from NMS into the core EU countries we apply the Poisson pseudo maximum likelihood estimator. Numerous literature contributions examine the main drivers of migration by using a fixed effects model as a baseline methodology. ${ }^{20}$ However, a fixed effect model does not allow for the estimation of variables that are constant in time (such as the distance between two countries). Moreover, Santos-Silva and Tenreyro (2006) in their paper show that parameters in log-linearized models estimated by OLS in the presence of heteroscedasticity could lead to biased estimates. The authors alternatively propose application of the Poisson pseudo maximum likelihood (PPML) estimator and argue that the PPML estimator is more suitable, given its consistency in presence of heteroscedasticity. Moreover, the PPML estimator will allow us to properly account for zero migration flows between two countries since the dependent variable in PPML is not in logarithmic form but is assumed to take positive integer values. Given this advantages of the PPML estimator over the standard panel fixed effects estimator we transform our basic gravity model from equation (1) and extend it by additional explanatory variables:

$$
m_{i j t}=\beta \log \left(X_{i t}\right)+\gamma \log \left(Y_{j t}\right)+\delta_{i}+\vartheta_{j}+\varepsilon_{i j t}
$$

where $m_{i j t}$ represents migration from origin country $i$ into destination country $j$ in a year $t, x_{i t}$ is a vector of explanatory variables characteristic for origin country economic, political, geographical and demographic factors, $y_{j t}$ is vector of explanatory variables representing destination country characteristics in time and $\delta_{i}$ and $\vartheta_{j}$ are respectively origin and destination country specific effects.

\section{RESULTS - MAIN DETERMINANTS OF EMIGRATION}

The main results of the estimation of equation (2) using the PPML estimator are presented in table 2. As a robustness check, estimates obtained by the application of the fixed effect model are also presented in table 2 but are not discussed explicitly. According to the results of the baseline model (Model 1), population and distance parameters are in line with gravity model predictions. An increase in distance between destination and origin country by $1 \%$ will decrease emigration flows by $1.5 \%$, all other factors being equal, confirming the theoretical predictions of the

\footnotetext{
${ }^{19}$ We opt for the exclusion of GDP per capita in PPS from the extended model specification since inclusion of GDP PC in PPS and short term economic indicators could result in multicollinearity. Instead, differences in level of economic development are captured by origin and destination fixed effects.

${ }^{20}$ A detailed overview of different estimation strategies and models used in assessment of impact of EU accession for CEE countries in 2004 is given in Brücker et al. (2009).
} 
standard gravity model implying that migration flows between two countries are inversely proportional to the distance between them. This interesting result suggests that importance of transportation and information costs that are approximated with physical distance between countries still remains relevant in migration decisions irrespective of the decrease in transportation costs and the development of the internet since the rather different world around the time of the pioneer application of gravity models in migration analysis in the late 1970s. The positive coefficient associated with the relative difference between population of destination and origin country suggests that countries with bigger populations have more intensive migration flows. However, this result is not statistically significant. Secondly, our baseline model shows GDP per capita in PPS in destination country increases migration flows directed toward the country, confirming the theories arguing that a positive difference in the level of economic conditions will increase emigration flows from origin to destination country. Estimated parameters show that an increase in GDP per capita in PPS in a destination country of $1 \%$ will lead to an increase in emigration flows from origin to destination country by $2.2 \%$, assuming all other factors remain unchanged. On other hand, the coefficients associated to GDP PC in PPS in origin country are not statistically significant.

Finally, the variable transitional provisions, measuring the impact of the accession to the principle of free movement of persons across borders going from new EU member states (origin countries) to the core EU (destination countries) is statistically significant and large in its value, increasing migration flow by $40 \%{ }^{21}$

The results of the extended model specification (Model 2) show that short-term economic indicators represented by different labour market indicators and cyclical position of the economy of origin and destination countries are statistically significant and thus affect emigration decisions. An increase in employment opportunities in a destination country by $1 \%$ will increase emigration flows from origin to destination countries by $8.2 \%$, all other factors being equal. At the same time, an increase in employment opportunities in origin country by $1 \%$ will decrease emigration flows by $5 \%$. Results indicate that cyclical position of the economy is also important for migration decisions. An improvement in cyclical position of a destination country by 1 percentage point (i.e. positive output gap) will increase emigration flows from origin to destination countries by $2 \%$, if all other factors remain constant.

\footnotetext{
${ }^{21}$ Changes in the predicted emigration flow for dummy variable representing transitional provisions are calulated according to the formula $e^{\beta_{t p}}-1$.
} 
TABLE 2

Determinants of emigration flows from new EU member states to the core EU countries between 2000 and 2016, Fixed effects estimator (FE) and Poisson pseudo maximum likelihood estimator (PPML).

Model 1

Model 1

(Baseline) FE (Baseline) PPML

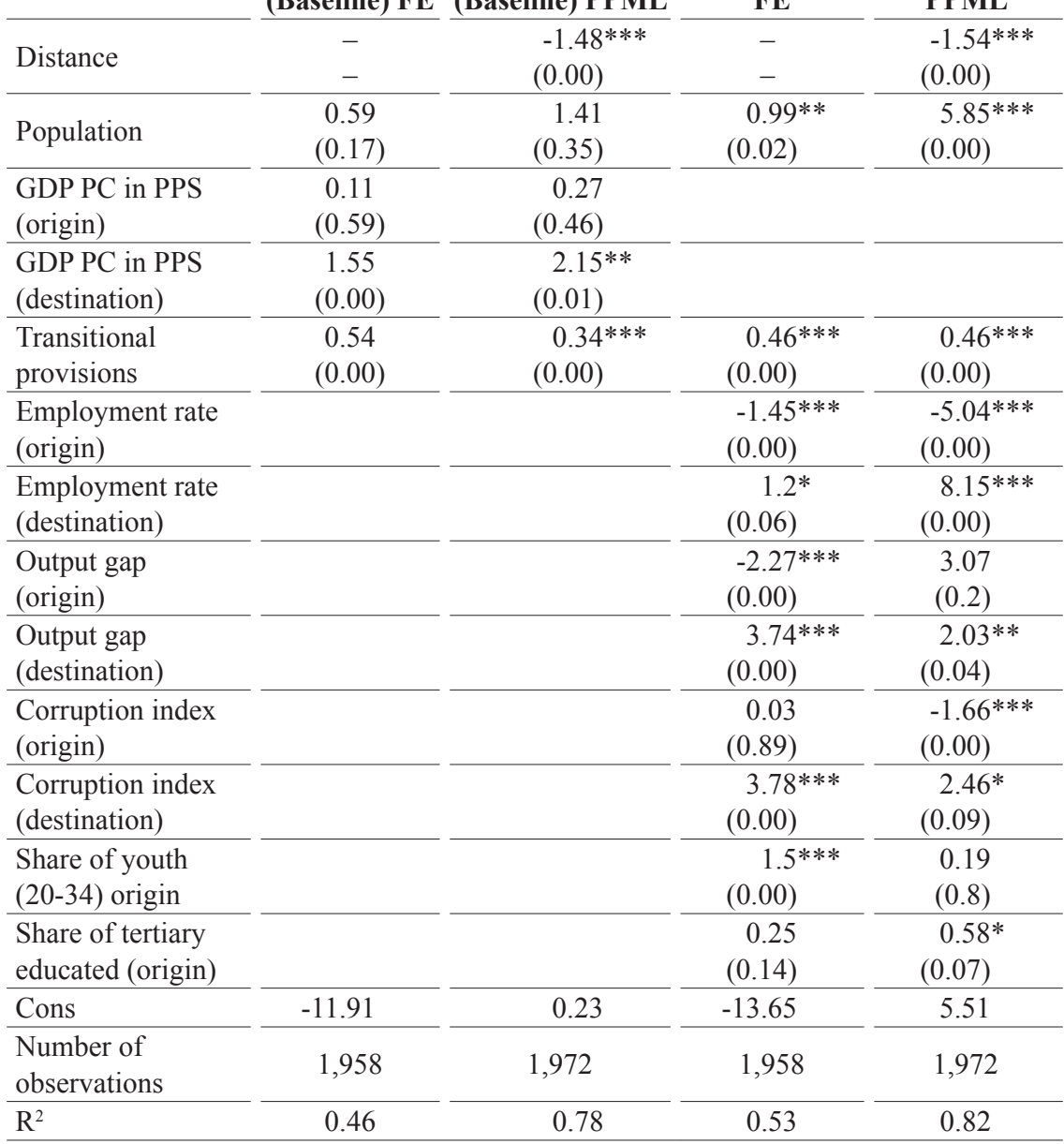

Note: *, ** and $* * *$ refer to $10 \%, 5 \%$ and $1 \%$ statistical significance levels, respectively. $P$-values are in parenthesis. All specifications include origin and destination fixed effects dummies. Parameters associated to output gap for origin and destination country are multiplied by 100 since the output gap enters the model specification in levels instead of being transformed into logarithms, due to negative values.

Source: Authors'elaboration based on national statistical offices of the core EU countries immigration data and on the data presented appendix 1 .

Moreover, we find an importance in the level of education of the workforce in the origin country, since the coefficient associated to the variable denoting the share of those with tertiary education in the total population of origin country assumes a positive, significant value. The estimates imply that an increase in the share of the tertiary educated in an origin population will increase migration flows from 
the origin country by $0.6 \%$. The share of young population in an origin country is also found to be positively correlated with the intensity of migration from the origin country but the results are not statistically significant. Finally, the difference in corruption between destination and origin countries is also significant for emigration decisions. An increase in the corruption index in the origin country by $1 \%$ (an increase in WGI corruption index represents a decrease of level of corruption in the economy, given the construction of corruption index) will lead to lower emigration from origin country by $1.7 \%$. At the same time, an increase in the corruption index of destination country by $1 \%$ (implying a lower corruption level in destination country) will increase emigration flows from origin to destination country on average by $2.5 \%$, all other factors being equal.

As a final step in our analysis, we compare results of the extended model specification with the baseline model specification and confirm the relevance of gravity model predictions for migration flows. The importance of EU accession, measured through the transitional provisions dummy variable again proved statistically significant and large in its value, suggesting that EU accession could raise emigration flows by $60 \%$, if all other factors remain unchanged. Overall, baseline and extended model specification results show that the possibility of free movement of people across borders gained with EU accession is the main trigger of intensification of emigration flows from NMS to the core EU countries. However, the new, higher level of emigration flows from NMS towards the core EU countries following EU accession differs among countries, ranging from $0.2 \%$ of the population as in the Czech Republic to almost $2 \%$ of population in Romania. According to the estimates of the gravity model, apart from the EU accession, significant determinants in explaining the magnitude of migration outflows are represented by the characteristics of origin country population itself, economic development and performance of short term economic indicators and level of institutional quality assessed through the corruption incidence of both origin (NMS) and destination countries (the core EU).

\subsection{ROBUSTNESS CHECKS}

In addition to static estimation models, as a robustness check we also estimate a dynamic model. We apply the Arellano and Bond (1991), and Blundell and Bond (1998) generalized method of moments estimator, which is suitable for datasets characterized by short-time periods and large cross sectional dimension with endogenous independent variable and in presence of fixed effects and heteroscedasticity and autocorrelation within observations. Inclusion of a lagged dependent variable is also relevant for assessment of network effect on emigration decisions, since lagged migration flow can be interpreted as network approximation. Controlling for network effect is important since networks offer support and an additional information set for migrants, reducing migration costs and associated risks (Beine, Docquier and Ozden, 2009). In line with previous model specifications, the dynamic model also contains origin dummies and destination dummies to take into account all unobservable time invariant origin and destination specific varia- 
bles that were not captured by the set of variables included in the model but are relevant for migration decisions and the intensity of migration flows. The results of the dynamic model corroborate the main findings from the previous section. The estimates confirm the importance of gravity model variables in the determination of emigration flows. Moreover, EU accession assessed through the transitional provisions variable again resulted as sizable and significant, increasing average emigration flows by $30 \%$. Finally, we confirm the importance of shortterm economic conditions - employment opportunities in origin country and changes in cyclical economic position in destination country as determinants of migration flows. Contrary to the static model specification, the impacts of the educational level of population in the origin country and the degree of corruption in the economy have the expected signs, but are not statistically significant. The results of dynamic model specification are presented in appendix 3.

\section{CONCLUSION}

This paper aimed to clarify some basic facts about the dynamics and main determinants of emigration from Croatia following EU accession. To that purpose, extensive data analysis was conducted, capturing and comparing different emigration data sources. Further, the application of panel gravity model to Croatian and other NMS indirect emigration data enabled us to detect and discuss the main determinants of emigration from Croatia and other NMS to the core EU countries and their importance in making decisions about emigration.

As a first contribution to the discussion of the issue of the current emigration wave in Croatia, we use mirror statistics from core EU national statistical offices and compare them to the official emigration numbers of CBS. Construction of an alternative emigration dataset using immigration data from the national statistical offices of the core EU countries showed that emigration flows from Croatia following EU accession are on average 2.6 times as high as those recorded in official statistical data, amounting to 230 thousand people leaving Croatia in the 2013-2016 period. If we relate our results to a priori projections of emigration from Croatia after EU accession, our estimates can be placed in between Vidovic and Mara (2015), and Strielkowski, Šárková and Żornaczuk (2013) ${ }^{22}$. Similar proportional population outflows were observed in less developed new member states following their EU accession (Romania and Bulgaria), while new member states from the initial wave of enlargement experienced less pronounced rises in their emigration flows.

Analysis of detailed migration data available at national statistical offices of the new EU member states statistical offices showed that average characteristics of emigrants from NMS are similar across countries and point to a balanced emigration with respect to the sex of the emigrants. The main destination country for most countries in the sample was Germany. Finally, data also show that the average emigrant from NMS in 2016 was between 31 and 37 years old, indicating that emigration affects the young part of the population. Emigration of mostly young

${ }^{22}$ Direct comparison is not possible since the aforementioned authors estimate net migration potential while our analysis is based on gross emigration flows. 
citizens is indisputably a human capital loss for origin countries. However, longterm overall effects of emigration flows on origin countries should be interpreted with caution. Emigration leads to improvement of knowledge and skills of emigrants, given that their skills increase due to exposure to international competition, instead of gradually deteriorating in the low capacity domestic labour market. In the case of reverse migration, this can result in a brain-gain for origin economies. Moreover, the effect of migration on the labour markets of origin countries is also twofold. According to the extensive migration literature (Thaut, 2009), the employment opportunities and wages of those who stay in origin countries increase and the unemployment rate decreases, causing the activation of long-term unemployed people. On other hand, labour market shortages in some sectors inevitably arise, and sustainability of public pensions and other social service are threatened. The overall effects will depend on synchronization of educational policies with origin country labour market requirements, overall degree of economic development and future economic performance in origin country.

In fact, the analysis of main determinants of migration showed the most significant factor in explaining emigration flows between NMS and the core EU countries is the accession to the principle of free movement of workers obtained by EU accession, which increased emigration flows in the range from $30 \%$ to $60 \%$. This is in line with other relevant studies about labour mobility within the EU, where EU membership is found to increase labour mobility significantly. ${ }^{23}$ However, estimation of the gravity model revealed that there exist other significant determinants in explaining migration outflows, such as: the characteristics of origin country populations itself, economic development, performance of short-term economic indicators and level of institutional quality assessed through the corruption incidence of both origin (NMS) and destination countries (the core EU). These findings imply that policies that promote broad and solid economic development can influence emigration flows, which raises several implications for policymakers.

Emigration phenomena will probably have a strong impact on the Croatian economy in the medium-run. Accordingly, we would like to emphasise the importance of further research in this field. Potential research topics encompass the assessment of the impact of the last emigration wave on the potential growth prospects of the Croatian economy, the effect of increasing remittances on the Croatian economy, sustainability of the current setup of social policies (pension funds, health system, new infrastructure investment, existing infrastructure maintenance), required immigration flows in order to alleviate negative emigration consequences, and finally the implications of emigration flows for the conduct of monetary, fiscal and structural policy in the broadest sense.

\section{Disclosure statement}

No conflict of interest.

${ }^{23}$ For more details about relationship between EU membership and labour mobility see Arpaia et al. (2016). 
TABLE A1

Data sources and details, independent variables

Data sources and details for set of independent variables

\begin{tabular}{|c|c|c|c|}
\hline Variable & Description & Source & $\begin{array}{c}\text { Estimation } \\
\text { details }\end{array}$ \\
\hline $\begin{array}{l}\text { GDP PC } \\
\text { in PPS }\end{array}$ & $\begin{array}{l}\text { Gross domestic product at market } \\
\text { prices, current prices, PPS per capita }\end{array}$ & $\begin{array}{l}\text { Eurostat } \\
\text { online } \\
\text { statistical } \\
\text { database } \\
\end{array}$ & $\begin{array}{l}\text { Destination and } \\
\text { origin country, } \\
\text { in } \log \end{array}$ \\
\hline $\begin{array}{l}\text { Unemployment } \\
\text { rate }\end{array}$ & $\begin{array}{l}\text { Yearly unemployment rates, from } 15 \\
\text { to } 64 \text { years, percentage }\end{array}$ & $\begin{array}{l}\text { Eurostat } \\
\text { online } \\
\text { statistical } \\
\text { database }\end{array}$ & $\begin{array}{l}\text { Destination and } \\
\text { origin country, } \\
\text { in } \log \end{array}$ \\
\hline Population & Population on 1 January, total & $\begin{array}{l}\text { Eurostat } \\
\text { online } \\
\text { statistical } \\
\text { database }\end{array}$ & $\begin{array}{l}\text { Relative values } \\
\text { between } \\
\text { destination and } \\
\text { origin country, } \\
\text { in log }\end{array}$ \\
\hline Distance & $\begin{array}{l}\text { "Distance between two countries is } \\
\text { calculated based on latitudes } \\
\text { and longitudes of the most important } \\
\text { cities/agglomerations (in terms of } \\
\text { population) Mayer and Zignago } \\
\text { (2011)". }\end{array}$ & $\begin{array}{l}\text { CEPII } \\
\text { database }\end{array}$ & In $\log$ \\
\hline $\begin{array}{l}\text { Youth } \\
\text { population } \\
\text { number }\end{array}$ & $\begin{array}{l}\text { Population on } 1 \text { January, from } 20 \text { to } \\
34 \text { years }\end{array}$ & $\begin{array}{l}\text { Eurostat } \\
\text { online } \\
\text { statistical } \\
\text { database }\end{array}$ & $\begin{array}{l}\text { Origin country, } \\
\text { as a share in } \\
\text { total population, } \\
\text { in } \log \end{array}$ \\
\hline $\begin{array}{l}\text { Tertiary } \\
\text { educated }\end{array}$ & $\begin{array}{l}\text { Population by educational attainment } \\
\text { level, from } 15 \text { to } 64 \text { years, tertiary } \\
\text { education (levels } 5-8 \text { ) }\end{array}$ & $\begin{array}{l}\text { Eurostat } \\
\text { online } \\
\text { statistical } \\
\text { database }\end{array}$ & $\begin{array}{l}\text { Origin country, } \\
\text { as a share in } \\
\text { total population, } \\
* 1000 \text {, in } \log \end{array}$ \\
\hline $\begin{array}{l}\text { Corruption } \\
\text { index }\end{array}$ & $\begin{array}{l}\text { Control of corruption captures } \\
\text { perceptions of the extent to which } \\
\text { public power is exercised for private } \\
\text { gain, including both petty and grand } \\
\text { forms of corruption, as well as } \\
\text { "capture" of the state by elites and } \\
\text { private interests (http://info. } \\
\text { worldbank.org/governance/ } \\
\text { WGI/\#doc) }\end{array}$ & $\begin{array}{l}\text { Worldwide } \\
\text { Governance } \\
\text { Indicators } \\
\text { (WGI), The } \\
\text { World Bank }\end{array}$ & $\begin{array}{l}\text { Destination and } \\
\text { origin country, } \\
\text { in } \log \end{array}$ \\
\hline
\end{tabular}




\begin{tabular}{|c|c|c|c|}
\hline Variable & Description & Source & $\begin{array}{c}\text { Estimation } \\
\text { details }\end{array}$ \\
\hline $\begin{array}{l}\text { Governance } \\
\text { index }\end{array}$ & $\begin{array}{l}\text { "Government effectiveness captures } \\
\text { perceptions of the quality of public } \\
\text { services, the quality of the civil } \\
\text { service and the degree of its } \\
\text { independence from political pressures, } \\
\text { the quality of policy formulation and } \\
\text { implementation, and the credibility of } \\
\text { the government's commitment to such } \\
\text { policies (http://info.worldbank.org/ } \\
\text { governance/WGI/\#doc)" }\end{array}$ & $\begin{array}{l}\text { Worldwide } \\
\text { Governance } \\
\text { Indicators } \\
\text { (WGI), The } \\
\text { World Bank }\end{array}$ & $\begin{array}{l}\text { Destination and } \\
\text { origin country, } \\
\text { in } \log \end{array}$ \\
\hline Output gap & $\begin{array}{l}\text { Output gaps ( } \% \text { of potential output }) \text {, } \\
\text { HP filter }\end{array}$ & $\begin{array}{l}\text { European } \\
\text { Commission } \\
\text { CIRCAB, II. } \\
\text { autum fore- } \\
\text { cast }\end{array}$ & $\begin{array}{l}\text { Destination and } \\
\text { origin country }\end{array}$ \\
\hline $\begin{array}{l}\text { Employment } \\
\text { rates }\end{array}$ & $\begin{array}{l}\text { Yearly employment rates, from } 15 \text { to } \\
64 \text { years, percentage }\end{array}$ & $\begin{array}{l}\begin{array}{l}\text { Eurostat } \\
\text { online } \\
\text { statistical } \\
\text { database }\end{array} \\
\end{array}$ & $\begin{array}{l}\text { Destination and } \\
\text { origin country, } \\
\text { in } \log \end{array}$ \\
\hline $\begin{array}{l}\text { Transitional } \\
\text { provisions }\end{array}$ & $\begin{array}{l}\text { Variable representing the access to } \\
\text { common free EU market for BG and } \\
\text { RO takes value } 1 \text { for FI, SE from } \\
2007 \text {, for DK from } 2009 \text {, for IT and } \\
\text { IE from } 2012 \text { and for all other } \\
\text { countries from } 2014 \text {. Variable } \\
\text { representing the access to common } \\
\text { free EU market for HR takes value } 1 \\
\text { for DK, FI, IR, SE from 2013, for BE, } \\
\text { IT, DE, LU from 2015, while NL, AT } \\
\text { and UK apply transitional provisions } \\
\text { for HR during the entire sample } \\
\text { period (sample is ending in } 2016 \text {, } \\
\text { while transitional provisions applied } \\
\text { by NL, AT and UK should be lifted by } \\
\text { June } 2018 \text { ). Variable representing the } \\
\text { access to common free EU market for } \\
\text { CZ, SK, SI, PL, HU, LV, LT, EE takes } \\
\text { value } 1 \text { for UK, SE, IE from } 2004 \text {, for } \\
\text { IT, FI from 2006, for NL, LU from } \\
\text { 2007, for BE, DK from } 2009 \text { and for } \\
\text { AT, DE from 2011 }\end{array}$ & $\begin{array}{l}\text { European } \\
\text { Commission }\end{array}$ & $\begin{array}{l}\text { Set of dummy } \\
\text { variables }\end{array}$ \\
\hline
\end{tabular}
the government's commitment to such policies (http://info.worldbank.org/ governance/WGI/\#doc)'” 
Data sources and details, dependent variable

Data Sources and details for set of independent variables

\begin{tabular}{|c|c|c|c|}
\hline Variable & Description & Source & Estimation details \\
\hline $\begin{array}{l}\text { Emigration } \\
\text { flows }\end{array}$ & $\begin{array}{l}\text { Data for IR, NL, FI, SE, } \\
\text { IT, AT, LU, DK avaliable } \\
\text { on line. Data for DE, BE, } \\
\text { UK obtained on email } \\
\text { request. Data for UK and } \\
\text { IE refers to immigration } \\
\text { numbers and not to official } \\
\text { migration statistics }\end{array}$ & $\begin{array}{l}\text { National statistical } \\
\text { offices websites of } \\
\text { core EU countries }\end{array}$ & $\begin{array}{l}\text { For static models - } \\
\text { emigration from origin } \\
\text { country } i \text { into destination } \\
\text { country } j \text { in time } t \text {, for } \\
\text { dynamic model - share } \\
\text { of emigrants in total } \\
\text { population of origin } \\
\text { country, in log }\end{array}$ \\
\hline
\end{tabular}

Data for Germany and Denmark are based on country of previous residence principle. Data for Netherlands, Italy, United Kingdom, and Belgium on country of birth principle, while data for Sweden, Finland, Luxemburg and Austria are based on citizenship principle.

Core EU countries are represented by 11 countries, due to data availability: Austria, Belgium, Denmark, Finland, Germany, Ireland, Italy, Luxemburg, Netherlands, Sweden and United Kingdom. Usually Portugal, Greece, Spain and France are also included in core EU countries. Required immigration data are not publicaly available on their website. Statistical office of Portugal delivered the data from our customized request. Since data are starting in 2008 we do not include them in main specifications. Upon conclusion of this paper we have not managed to receive required data from customized requests sent to other statistical offices. 


\section{TABLE A3}

Total migration flow in Croatia - approximation based on discretional combination of different data sources

\section{Emigration from and to Croatia} following the EU accession $2013 \stackrel{2014}{2015} 2016 \stackrel{2013-2016}{2}$

(1) Emigration to core EU $\begin{array}{llllll}\text { countries from national statistical } \quad 31,655 & 53,666 & 72,528 & 71,314 & 229,163\end{array}$ offices of core EU countries

\begin{tabular}{|c|c|c|c|c|c|}
\hline $\begin{array}{l}\text { (2) Emigration to "rest of the } \\
\text { world" according to CBS }\end{array}$ & 11,220 & 9,049 & 11,116 & 9,238 & 40,623 \\
\hline (3) Total emigration $=(1)+(2)$ & 42,875 & 62,715 & 83,644 & 80,552 & 269,786 \\
\hline (4) CNB total emigration & 15,262 & 20,858 & 29,651 & 36,436 & 102,207 \\
\hline (5) Emigration coefficient & 2.8 & 3.0 & 2.8 & 2.2 & 2.6 \\
\hline $\begin{array}{l}\text { (6) Immigration from core EU } \\
\text { countries according to national } \\
\text { statistical offices of core EU } \\
\text { countries }\end{array}$ & 14,164 & 19,346 & 23,261 & 23,422 & 80,193 \\
\hline $\begin{array}{l}\text { (7) Immigration from "rest of the } \\
\text { world" according to CBS }\end{array}$ & 8,676 & 8,540 & 8,512 & 9,705 & 35,433 \\
\hline (8) Total immigration $=(6)+(7)$ & 22,840 & 27,886 & 31,773 & 33,127 & 115,626 \\
\hline (9) CBS total immigration & 10,378 & 10,638 & 11,706 & 13,985 & 46,707 \\
\hline (10) Immigration coefficient & 2.2 & 2.6 & 2.7 & 2.4 & 2.5 \\
\hline (11) Net emigration $=(3)-(8)$ & 20,035 & 34,829 & 51,871 & 47,425 & 154,160 \\
\hline (12) CNB net emigration & 4,884 & 10,220 & 17,945 & 22,451 & 55,500 \\
\hline (13) Net emigration coefficient & 4.1 & 3.4 & 2.9 & 2.1 & 2.8 \\
\hline
\end{tabular}

Note: UK and Ireland not included in immigration numbers.

Source: CBS and national statistical offices of the core EU countries. 
APPENDIX 3

\section{TABLe A4}

Determinants of emigration flows from new EU member states to the core EU countries between 2000 and 2016, dynamic estimation, Arellano-Bond GMM estimator

Model 3 Dynamic Model (GMM)

Distance

$-0.49 * * *$

Population

0.29

$(0.59)$

Transitional provisions

$0.25^{* * *}$

$(0.00)$

Employment rate (origin)

$-2.01 * * *$

$(0.00)$

Employment rate (destination)

0.53

$(0.47)$

Output gap (origin)

3.72

(0.36)

Output gap (destination)

$2.18^{* * *}$

(0.00)

$-0.37$

Corruption index (origin)

Corruption index (destination)

Corruption index (destination)

Share of youth (20-34), origin $-0.32$

Share of tertiary educated (origin)

$\ln (\mathrm{m} \mathrm{t}-1)$

Cons 7.4

Note: *,** and *** refer to $10 \%, 5 \%$ and $1 \%$ statistical significance levels, respectively. $P$-values are in parenthesis. All specifications include origin and destination fixed effects dummies. Parameters associated to output gap for origin and destination country are multiplied by 100 since the output gap enters the model specification in levels instead of being transformed into logarithms, due to negative values.

Source: Authors' elaboration based on national statistical offices of the core EU countries immigration data and on the data presented in appendix 1. 
TABLE A5

Determinants of emigration flows from new EU member states to the core EU countries between 2000 and 2016, Poisson pseudo maximum likelihood estimator, extended specification Model 4

Model 4 FE Model 4 PPML

\begin{tabular}{|c|c|c|}
\hline Distance & $\begin{array}{l}- \\
- \\
\end{array}$ & $\begin{array}{l}-1.52 * * * \\
(0.00)\end{array}$ \\
\hline Population & $\begin{array}{l}1.69^{* * *} \\
(0.00)\end{array}$ & $\begin{array}{l}6.63^{* * * *} \\
(0.00)\end{array}$ \\
\hline Transitional provisions & $\begin{array}{l}0.47 * * * \\
(0.00)\end{array}$ & $\begin{array}{l}0.42^{* * *} \\
(0.00)\end{array}$ \\
\hline Unemployment rate (origin) & $\begin{array}{l}0.19^{* *} \\
(0.03)\end{array}$ & $\begin{array}{l}0.69^{* * *} \\
(0.00)\end{array}$ \\
\hline Unemployment rate (destination) & $\begin{array}{r}-0.03 \\
(0.66) \\
\end{array}$ & $\begin{array}{l}-1.09^{* * * *} \\
(0.00)\end{array}$ \\
\hline Output gap (origin) & $\begin{array}{l}2.18^{* * *} \\
(0.01)\end{array}$ & $\begin{array}{r}1.53 \\
(0.34) \\
\end{array}$ \\
\hline Output gap (destination) & $\begin{array}{l}4.64 * * * \\
(0.00)\end{array}$ & $\begin{array}{c}2.52^{*} \\
(0.09)\end{array}$ \\
\hline Governance index (origin) & $\begin{array}{r}-0.22 \\
(0.52) \\
\end{array}$ & $\begin{array}{l}-2.29 * * * \\
(0.00)\end{array}$ \\
\hline Governance index (destination) & $\begin{array}{r}0.89 \\
(0.11)\end{array}$ & $\begin{array}{l}-2.71 \\
(0.40)\end{array}$ \\
\hline Share of youth (20-34), origin & $\begin{array}{l}1.71 * * * \\
(0.00)\end{array}$ & $\begin{array}{r}1.34 \\
(0.11)\end{array}$ \\
\hline Share of tertiary educated (origin) & $\begin{array}{l}0.41 * * \\
(0.02)\end{array}$ & $\begin{array}{l}0.69 * * \\
(0.01)\end{array}$ \\
\hline Cons & -1.04 & $42.2 * *$ \\
\hline Number of observations & 1,958 & 1,972 \\
\hline $\mathrm{R}^{2}$ & 0.51 & 0.82 \\
\hline
\end{tabular}

Note: $*, * *$ and $* * *$ refer to $10 \%, 5 \%$ and $1 \%$ statistical significance levels, respectively. $P$-values are in parenthesis. All specifications include origin and destination fixed effects dummies. Parameters associated to output gap for origin and destination country are multiplied by 100 since the output gap enters the model specification in levels instead of being transformed into logarithms, due to negative values.

Source: Authors' elaboration based on national statistical offices of the core EU countries immigration data and on the data presented in appendix 1 . 


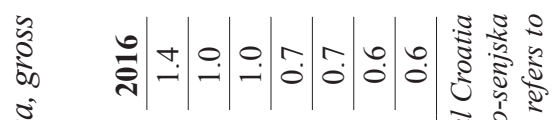

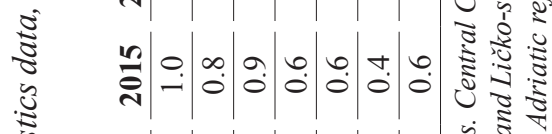

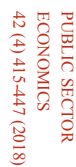

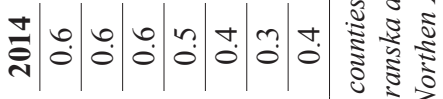

m.

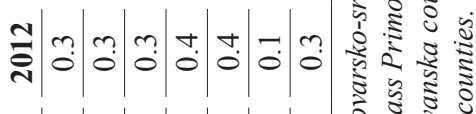

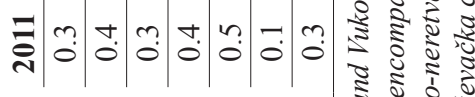

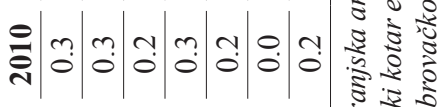

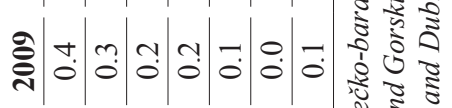

का

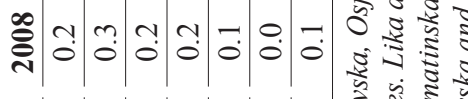

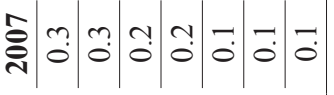

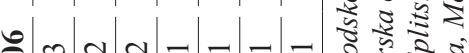

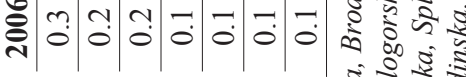

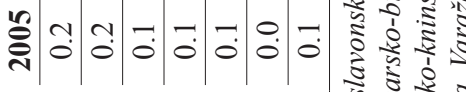

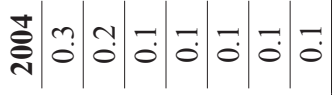

¿

ว

s

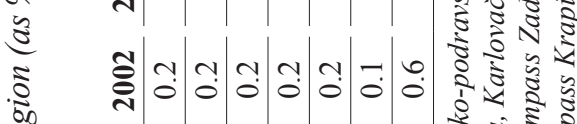

क्ष

3

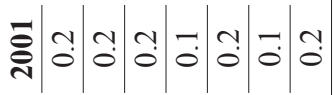

8

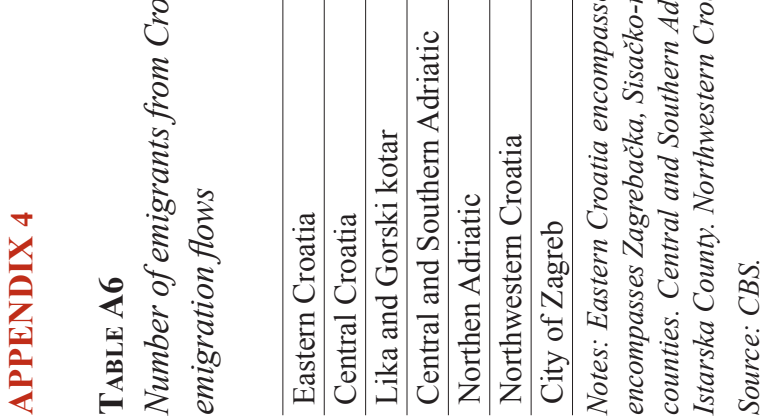

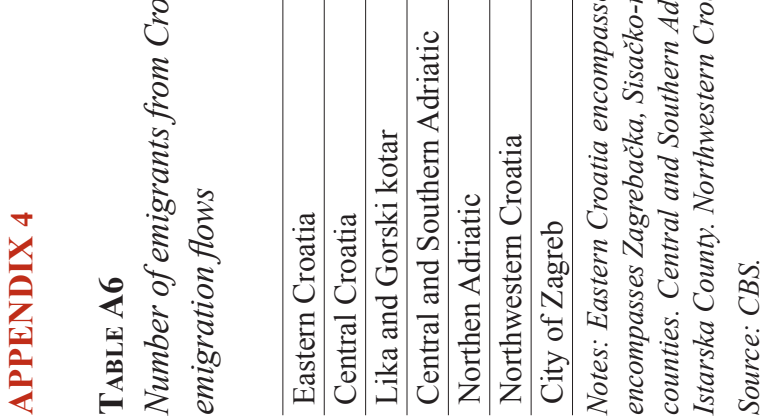

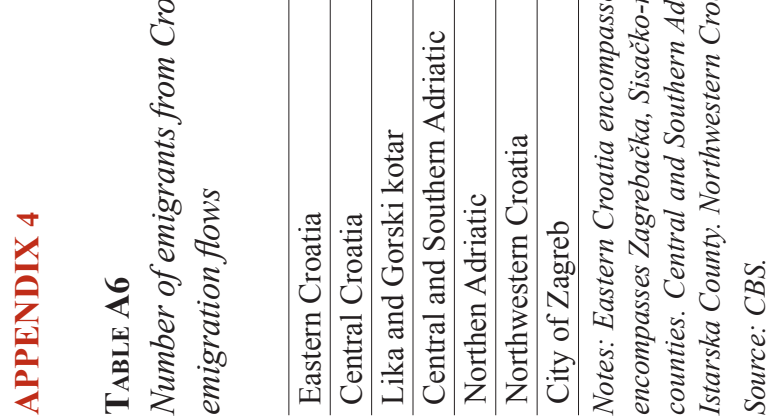
जे है के च

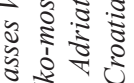




\section{REFERENCES}

1. Anderson, J. E., 2011. The Gravity Model. Annual Review of Economics, Annual Reviews, 3(1), pp. 133-160.

2. Arellano, M. and Bond, S., 1991. Some tests of specification for panel data: Monte Carlo evidence and an application to employment equations. Review of Economic Studies, 58(2), pp. 277-297. https://doi.org/10.2307/2297968

3. Arpaia, A. [et al.], 2016. Labour mobility and labour market adjustment in the EU. IZA Journal of Devlopment and Migration, 5(21), pp. 1-37. https://doi. org/10.1186/s40176-016-0069-8

4. Beine, M., Bourgeon, P. and Bricongne, J. C., 2017. Aggregate Fluctuations and International Migration. Scand. Journal of Economics. Accepted Author Manuscript. https://doi.org/10.1111/sjoe.12258

5. Beine, M., Docquier, F. and Ozden, C., 2009. Diasporas. Journal of Development Economics, 95(1), pp. 30-41. https://doi.org/10.1016/j.jdeveco.2009. 11.004

6. Bertoli, S., Brücker, H. and Fernández-Huertas Moraga, J., 2013. The European Crisis and Migration to Germany: Expectations and the Diversion of Migration Flows. IZA Discussion Papers, No. 7170. Available at: <http://ftp. iza.org/dp7170.pdf>.

7. Blundell, R., and Bond S., 1998. Initial conditions and moment restrictions in dynamic panel data models. Journal of Econometrics, 87(1), pp. 115-143. https://doi.org/10.1016/S0304-4076(98)00009-8

8. Borjas, G. J., 1987. Self-Selection and the Earnings of Immigrants. The American Economic Review, 77(4), pp. 531-553.

9. Božić, S. and Burić, B., 2005. Migracijski potencijal Hrvatske-mikroanalitički aspekti. Migracijske i etničke teme, 21(1-2), pp. 9-33.

10. Brücker, H. [et al.], 2009. Labour mobility within the EU in the context of enlargement and the functioning of the transitional arrangements. Nuremberg: European Integration Consortium Final Report. Available at: <http:// ec.europa.eu/social/BlobServlet?docId=2509\&langId=en $>$.

11. Eurostat, 2018. Eurostat International Migration Statistics. Available at: $<$ https://ec.europa.eu/eurostat/cache/metadata/en/migr_immi_esms.htm>.

12. Fertig, M. and Kahanec, M., 2013. Mobility in an Enlarging European Union: Projections of Potential Flows from EU's Eastern Neighbors and Croatia. IZA Discussion Papers, No. 7634. Available at: < http://ftp.iza.org/dp7634.pdf>.

13. Flowerdew, R. and Salt, J., 1979. Migration between labour market areas in Great Britain, 1970-1971. Journal Regional Studies, 13(2), pp. 211-231. https://doi.org/10.1080/09595237900185181

14. Grogger, J. and Hanson, G. H., 2011. Income Maximization and the selection and sorting of international Migrants. Journal of Development Economics, 95(1), pp. 42-54. https://doi.org/10.1016/j.jdeveco.2010.06.003

15. Harris, J. R. and Todaro, M. P., 1970. Migration, Unemployment and Development. A Two-Sector Analysis. The American Economic Review, 60(1), pp. 126-142. 
16. Hazans, M. and Philips, K., 2011. The Post-Enlargement Migration Experience in the Baltic Labor Markets. IZA DP, No. 5878. Available at: $<$ http://ftp. iza.org/dp5878.pdf $>$.

17. HZZ, 2017. Anketa poslodavaca 2017. Zagreb: Hrvatski zavod za zapošljavanje. Available at: <http://www.hzz.hr/UserDocsImages/Anketa_poslodavaca_2017_HZZ.pdf $>$.

18. Izquierdo, M., Jimeno, J. F. and Lacuesta, F., 2014. The Impact of the Crisis on Migration Flows in Spain. Intereconomics, 49(3), pp. 144-151.

19. Jurić, T., 2017. Suvremeno iseljavanje Hrvata u Njemačku: karakteristike i motivi. Migracijske i etničke teme, 24(3), pp. 337-371.

20. Lamberty, L., 2015. Explaining Baltic Migration After EU Accession: Determinants and Consequences. Available at: <https://www.ehl.lu.se/media/ehl/ snee/papers/lamberty.pdf>.

21. Ordinance for the implementation of the General Tax Act, OG 30/17. Zagreb: Official Gazzete.

22. Poot, J. [et al.], 2016. The gravity model of migration: the successful comeback of an ageing superstar in regional science. Investigaciones Regionales Journal of Regional Research, 36, pp. 63-86.

23. Poprawe, M., 2015. On the relationship between corruption and migration: empirical evidence from a gravity model of migration. Public Choice, 163(3), pp. 337-354. https://doi.org/10.1007/s11127-015-0255-X

24. Ramos, R., 2016. Gravity models: A tool for migration analysis. IZA World of Labor 2016, No. 239. https://doi.org/10.15185/izawol.239

25. Santos Silva, J. M. and Tenreyro S., 2006. The log of gravity. The Review of Economics and Statistics, 88(4), pp. 641-658. https://doi.org/10.1162/rest. 88.4.641

26. Sjaastad, L. A., 1962. The Costs and Returns of Human Migration. Journal of Political Economy, 70(5), pp. 80-93. https://doi.org/10.1086/258726

27. Sprenger, E., 2013. The Determinants of International Migration in the European Union: An Empirical Analysis. IOS Working Papers, No. 325. Available at: <https://www.econstor.eu/bitstream/10419/79240/1/733903029.pdf>.

28. Statistics Poland, 2011. The concept of the international migration statistic system in Poland. Available at: <https://stat.gov.pl/cps/rde/xbcr/gus/p_inter migration_stat_system_in_poland.pdf $>$.

29. Strielkowski, W., Šárková, K. and Żornaczuk T., 2013. EU Enlargement and Migration: Scenarios of Croatian Accession. Romanian Journal of European Affairs, 13(3), pp. 53-63. https://doi.org/10.2139/ssrn.2334173

30. Šonje V., 2018. Nepovratna emigracija: prva procjena. Available at: <http:// arhivanalitika.hr/blog/nepovratna-emigracija-prva-procjena/>.

31. Thaut L., 2009. EU Integration \& Emigration Consequences: The Case of Lithuania. International Migration, 47(1), pp. 192-233. https://doi.org/ 10.1111/j.1468-2435.2008.00501.x 
32. Tinbergen, J., 1962. Shaping the World Economy: Suggestions for an International Economic Policy. New York: The Twentieth Century Fund.

33. Vidovic, H. and Mara, I., 2015. Free Movement of Workers, Transitional Arrangements and Potential Mobility from Croatia. The Vienna Institute for International Economic Studies Research Report, No. 402. Available at: $<$ https://wiiw.ac.at/free-movement-of-workers-transitional-arrangementsand-potential-mobility-from-croatia-dlp-3630.pdf $>$.

34. Vuković, V., 2017. The political economy of local government in Croatia: winning coalitions, corruption, and taxes. Public Sector Economics, 41(4), pp. 387-421. https://doi.org/10.3326/pse.41.4.1

35. Župarić-Ilijć D., 2016. Iseljavanje iz Republike Hrvatske nakon ulaska u Europsku uniju. Zagreb: Friedrich Ebert Stiftung. Available at: $<\mathrm{http}$ ://www. fes-croatia.org/fileadmin/user_upload/FES_Iseljavanje_web.pdf $>$. 